\title{
Subject Index 2007
}

A

\section{adolescents}

Recent substance use and high levels of psychological distress among secondary school students in New South Wales. 2007; 18(8): 125-9

alcohol

Reducing alcohol-related violence and improving community safety: the Alcohol Linking Program. 2007; 18(6): 83-5

Recent substance use and high levels of psychological distress among secondary school students in New South Wales. 2007; 18(8): 125-9

Alcohol Linking Program

Reducing alcohol-related violence and improving community safety: the Alcohol Linking Program. 2007; 18(6): 83-5

Area Health Services

Influencing population health performance: introduction of standards for area health services in New South Wales. 2007; 18(2): 17-21

\section{Australia}

Developing a national approach to building healthy and sustainable cities. 2007 ; 18(4): 45-7

\section{B}

\section{Bug Breakfast}

Bug Breakfast Delivery Manual available on the NSW Health Intranet. 2007; 18(2): 8

\section{Bug Breakfast in the Bulletin}

Bug Breakfast in the Bulletin: refugee health. 2007; 18(2): 26-7

Bug Breakfast in the Bulletin: Ross River virus. 2007; 18(4): 63-4

Bug Breakfast in the Bulletin: Human Papilloma Virus. 2007; 18(6): 97-8

Bug Breakfast in the Bulletin: Q fever. 2007; 18(8): 137-8

Bug Breakfast in the Bulletin: Climate change and infectious diseases. 2007; 18(12): 243-4

C

cannabis see marijuana

capacity building

Building health impact assessment capacity as a lever for healthy public policy in urban planning. 2007; 18(10): 192-4

Health impact assessment and urbanisation. Lessons from the NSW HIA Project. 2007; 18(10): 198-201

Centers for Disease Control (USA)

Healthy Places initiative. 2007; 18(12): 213

Centre for Health Equity Training, Research and Evaluation (CHETRE)

International perspective on health impact assessment in urban settings. 2007; 18(10): 152-4

cervical cancer

Bug Breakfast in the Bulletin: Human Papilloma Virus. 2007; 18(6): 97-8

\section{Chadwick, Edwin}

Will considerations of environmental sustainability revitalise the policy links between the urban environment and health? 2007; 18(4): 41-5

Channelling Edwin Chadwick: beyond utopian thinking in urban planning policy and health. 2007; 18(10): 195-7

cholera

Three cholera cases linked to eating raw imported whitebait. $2007 ; 18(2): 28-35$

\section{climate change}

Bug Breakfast in the Bulletin: Climate change and infectious diseases. 2007; 18(12): 243-4

communicable diseases

Bug Breakfast in the Bulletin: Climate change and infectious diseases. $2007 ; 18(12)$ : 243-4

communicable diseases - reporting

Communicable Diseases Report, New South Wales, for November and December 2006. 2007; 18(2): 28-35

Communicable Diseases Report, New South Wales, for January and February 2007. 2007; 18(4): 66-71

Communicable Diseases Report, New South Wales, for March and April 2007. 2007; 18(6): 100-3

Communicable Diseases Report, New South Wales, for May and June 2007. 2007; 18(8): 140-7

Communicable Diseases Report, New South Wales, for July and August 2007. 2007; 18(10): 203-7

Communicable Diseases Report, New South Wales, for September and October 2007. 2007; 18(12): 246-50

community consultation

Strengthening the effectiveness of 'whole of government' interventions to break the cycle of violence in disadvantaged communities. 2007; 18(6): 94-6

correctional institutions

Prevalence of Mantoux positivity and annual risk of infection for tuberculosis in New South Wales prisoners, 1996 and 2001. 2007; 18(8): 119-24

CPTED see Crime Prevention Through Environmental Design (CPTED)

crime

Public health and the potential benefits of Crime Prevention Through Environmental Design. 2007; 18(12): 232-7

Crime Prevention Through Environmental Design

(CPTED)

Public health and the potential benefits of Crime Prevention Through Environmental Design. 2007; 18(12): 232-7

cryptosporidiosis

Factsheet: Cryptosporidiosis. 2007; 18(2): 25-6

Statewide outbreak of cryptosporidiosis in NSW, November 2005-May 2006. 2007; 18(8): 140-7

D

\section{data collection}

Preventing violence in New South Wales: data sources and their adequacy. $2007 ; 18(6): 75-82$ 
A discussion of the potential benefits to injury surveillance through inclusion of date of injury in hospitalisation data in New South Wales and Australia. 2007; 18(8): 130-2

\section{diphtheria}

Factsheet: diphtheria. 2007; 18(8): 139

disaster response planning

Health surveillance among a team of Australian health workers assisting tsunami victims in Aceh, Indonesia. 2007; 18(2): 22-4

domestic violence

The NSW Health routine screening for domestic violence program. 2007; 18(6): 86-9

Leaving violent relationships and avoiding homelessness providing a choice for women and their children. 2007; 18(6): 90-3

drug use - health aspects

Recent substance use and high levels of psychological distress among secondary school students in New South Wales. 2007; 18(8): 125-9

E

environmental health

A social-ecological perspective on health in urban environments. 2007; 18(4): 48-50

Bug Breakfast in the Bulletin: Climate change and infectious diseases. 2007; 18(12): 243-4

Sustain. 2007; 18(12): 213

see also sustainable development

environmental impact statements

Health impact assessment and urbanisation. Lessons from the NSW HIA Project. 2007; 18(10): 198-201

epireviews

Pertussis in New South Wales, 1993-2005: the impact of vaccination policy on pertussis epidemiology. 2007; 18(4): 55-61

equity

Health impact assessment and urbanisation. Lessons from the NSW HIA Project. 2007; 18(10): 198-201

$\mathrm{F}$

\section{factsheets}

Factsheet: Cryptosporidiosis. 2007; 18(2): 25-6

Factsheet: Legionnaires' disease. 2007; 18(4): 65

Factsheet: Mumps. 2007; 18(6): 99

Factsheet: Diphtheria. 2007; 18(8): 139

Factsheet: Hepatitis C. 2007; 18(10): 202-3

Factsheet: Yellow fever. 2007; 18(12): 245

federal government see Australia

Fenner Conference on the Environment

Creating healthy, just and eco-sensitive cities. 2007; 18(4): $37-40$

Healthy, just and eco-sensitive cities: moving forward. 2007; 18(12): 209-12

\section{food-borne diseases}

Two blue families: unintentional ingestion of sodium nitrite. 2007 ; 18(2): 28-35

Histamine (scombroid) fish poisoning. 2007; 18(4): 66-71

Enteric diseases. 2007; 18(8): 140-7

\section{G}

\section{gastroenteritis}

Enterics. 2007; 18(10): 203-7 global warming see climate change

$\mathrm{H}$

haemolytic uraemic syndrome

Recent increase in haemolytic uraemic syndrome cases. 2007; 18(2): 28-35

health impact assessment (HIA)

Report on the health impact assessment of the Sydney Metropolitan Strategy in greater western Sydney. 2007; 18(4): 40

Health impact assessment in urban settings. 2007; 18(10): 149-50

Influencing urban environments for health: NSW Health's response. 2007 ; 18(10): 150-1

International perspective on health impact assessment in urban settings. 2007; 18(10): 152-4

Health impacts of urban development: key considerations. 2007; 18(10): 155-6

A planner's perspective on the health impacts of urban settings. 2007 ; 18(10): 157-60

Learning by doing: the value of case studies of health impact assessment. 2007; 18(10): 161-3

Bungendore health impact assessment: urban development in a rural setting. 2007; 18(10): 164-5

An equity-focussed social impact assessment of the Lower Hunter Regional Strategy. 2007; 18(10): 166-8

Greater Granville Regeneration Strategy. 2007; 18(10): 169-71

A health impact assessment of the Liverpool Hospital redevelopment. 2007; 18(10): 172-3

Rapid versus intermediate health impact assessment of foreshore development plans. 2007; 18(10): 174-6

Health and social impact assessment of the South East Queensland Regional Plan (2005-2026). 2007; 18(10): 177-9

Lessons in applying health impact assessment to regeneration schemes: the Victorian experience. 2007; 18(10): 180-1

Greater Christchurch Draft Urban Development Strategy 2005. 2007; 18(10): 182-4

Health impact assessments in London: assessing the Lord Mayoral strategies. 2007; 18(10): 185-7

An overview of the regulatory planning system in New South Wales: identifying points of intervention for health impact assessment and consideration of health impacts. 2007; 18(10): 188-91

Building health impact assessment capacity as a lever for healthy public policy in urban planning. 2007; 18(10): 192-4

Health impact assessment and urbanisation. Lessons from the NSW HIA Project. 2007; 18(10): 198-201

Public health and the potential benefits of Crime Prevention Through Environmental Design. 2007; 18(12): 232-7

\section{health planning}

Influencing urban environments for health: NSW Health's response. 2007 ; 18(10): 150-1

A planner's perspective on the health impacts of urban settings. 2007; 18(10): 157-60

An equity-focussed social impact assessment of the Lower Hunter Regional Strategy. 2007; 18(10): 166-8

Greater Granville Regeneration Strategy. 2007; 18(10): $169-71$ 
An overview of the regulatory planning system in New South Wales: identifying points of intervention for health impact assessment and consideration of health impacts. 2007; 18(10): 188-91

Building health impact assessment capacity as a lever for healthy public policy in urban planning. 2007; 18(10): 192-4

Channelling Edwin Chadwick: beyond utopian thinking in urban planning policy and health. 2007; 18(10): $195-7$

Public health and the potential benefits of Crime Prevention Through Environmental Design. 2007; 18(12): $232-7$

Healthy, just and eco-sensitive cities: moving forward. 2007; 18(12): 209-12

Healthy by Design: an innovative planning tool for the development of safe, accessible and attractive environments. 2007; 18(12): 228-31

health policy

Influencing population health performance: introduction of standards for area health services in New South Wales. 2007; 18(2): 17-21

health promotion - physical activity

Healthy by Design: an innovative planning tool for the development of safe, accessible and attractive environments. 2007 ; 18(12): 228-31

hepatitis A

Hepatitis A clinic. 2007; 18(6): 100-3

hepatitis B

Enhanced surveillance of hepatitis B infection in innerwestern Sydney. 2007; 18(8): 115-18

hepatitis $\mathbf{C}$

HCV investigation. 2007; 18(6): 100-3

Factsheet: Hepatitis C. 2007; 18(10): 202-3

history of public health

Will considerations of environmental sustainability revitalise the policy links between the urban environment and health?. 2007; 18(4): 41-5

Channelling Edwin Chadwick: beyond utopian thinking in hospitals urban planning policy and health. 2007; 18(10): 195-7

A health impact assessment of the Liverpool Hospital redevelopment. 2007; 18(10): 172-3

\section{Howard, Ebenezer}

Will considerations of environmental sustainability revitalise the policy links between the urban environment and health?. 2007; 18(4): 41-5

HPV see Human Papilloma Virus

Human Papilloma Virus

Bug Breakfast in the Bulletin: Human Papilloma Virus. 2007; 18(6): 97-8

I

\section{immunisation}

Health surveillance among a team of Australian health workers assisting tsunami victims in Aceh, Indonesia. 2007; 18(2): 22-4

Bug Breakfast in the Bulletin: Human Papilloma Virus. 2007; 18(6): 97-8

A review of the efficacy of human Q fever vaccine registered in Australia. 2007; 18(8): 133-6 inequalities

Crowded suburbs and killer cities: a brief review of the relationship between urban environments and mental health. 2007; 18(12): 222-7

\section{influenza}

Influenza surveillance for NSW in 2006. 2007; 18(2): 28-35

Influenza. 2007; 18(8): 140-7, 2007; 18(10): 203-7, 2007; 18(12): $246-50$

information technology

Use of communication technology among public health professionals in New South Wales, Australia. 2007; 18(2): 13-16

injuries and accidents

A discussion of the potential benefits to injury surveillance through inclusion of date of injury in hospitalisation data in New South Wales and Australia. 2007; 18(8): 130-2

\section{Internet}

Future directions for the Bulletin. 2007; 18(2): 1-2

Use of communication technology among public health professionals in New South Wales, Australia. 2007; 18(2): $13-16$

intranet

Bug Breakfast Delivery Manual available on the NSW Health Intranet. 2007; 18(2): 8

$\mathrm{L}$

legal issues

An overview of the regulatory planning system in New South Wales: identifying points of intervention for health impact assessment and consideration of health impacts. 2007; 18(10): 188-91

legionellosis

Factsheet: Legionnaires' disease. 2007; 18(4): 65

Legionnaires' disease - Circular Quay. 2007; 18(4): 66-71

Legionnaires' disease. 2007; 18(8): 140-7

listeriosis

Enterics. 2007; 18(12): 246-50

M

marijuana

Recent substance use and high levels of psychological distress among secondary school students in New South Wales. 2007; 18(8): 125-9

meningococcal disease

Meningococcal disease. 2007; 18(8): 140-7, 2007; 18(10): 203-7, 2007; 18(12): 246-50

mental illness

Recent substance use and high levels of psychological distress among secondary school students in New South Wales. 2007; 18(8): 125-9

Crowded suburbs and killer cities: a brief review of the relationship between urban environments and mental health. 2007 ; 18(12): 222-7

methaemoglobinaemia

Two blue families: unintentional ingestion of sodium nitrite. 2007; 18(2): 28-35

mosquitoes

Bug Breakfast in the Bulletin: Ross River virus. 2007; 18(4): $63-4$

Factsheet: Yellow fever. 2007; 18(12): 245 
mumps

Mumps in North Coast Area Health Service. 2007; 18(4): 66-71

Factsheet: Mumps. 2007; 18(6): 99

Mumps. 2007; 18(12): 246-50

$\mathrm{N}$

\section{New Zealand}

Greater Christchurch Draft Urban Development Strategy 2005. 2007; 18(10): 182-4

norovirus

Norovirus outbreak in a tour group. 2007; 18(4): 66-71

notifiable diseases reporting system

Enhanced surveillance of hepatitis B infection in innerwestern Sydney. 2007; 18(8): 115-18

notifications - enteric diseases

Enteric diseases. 2007; 18(8): 140-7

Enterics. 2007; 18(10): 203-7, 2007; 18(12): 246-50

notifications - Year in Review

Year in review: communicable disease surveillance, New South Wales, 2006. 2007; 18(8): 105-14

\section{NSW Public Health Bulletin}

Future directions for the Bulletin. 2007; 18(2): 1-2 nutrition

Healthy, just and eco-sensitive cities: moving forward. 2007; 18(12): 209-12

0

obesity

Seeing obesity as a systems problem. 2007; 18(12): 214-18

obituaries

Obituary: Professor Aileen Plant (1948-2007). 2007; 18(4): 62

outbreaks in institutions

Enteric diseases. 2007; 18(8): 140-7

overseas relief missions

Health surveillance among a team of Australian health workers assisting tsunami victims in Aceh, Indonesia. 2007; 18(2): 22-4

P

pertussis (whooping cough)

Pertussis in New South Wales, 1993-2005: the impact of vaccination policy on pertussis epidemiology. 2007; 18(4): 55-61

False positive pertussis serological tests. 2007; 18(4): $66-71$

Year in review: communicable disease surveillance, New South Wales, 2006. 2007; 18(8): 105-14

physical activity

Can the impact on health of a government policy designed to create more liveable neighbourhoods be evaluated? An overview of the RESIDential Environment Project. 2007; 18(12): 238-42

Healthy by Design: an innovative planning tool for the development of safe, accessible and attractive environments. 2007; 18(12): 228-31

Active Living by Design. 2007; 18(12): 213

NSW Premier's Council for Active Living. 2007; 18(12): 213

Plant, Aileen

Obituary: Professor Aileen Plant. 2007; 18(4): 62 police

Reducing alcohol-related violence and improving community safety: the Alcohol Linking Program. 2007; 18(6): 83-5

population health

Influencing population health performance: introduction of standards for area health services in New South Wales. 2007; 18(2): 17-21

prisoners

Prevalence of Mantoux positivity and annual risk of infection for tuberculosis in New South Wales prisoners, 1996 and 2001. 2007; 18(8): 119-24

problem-based learning

Problem-based learning in public health workforce training: a discussion of educational principles and evidence. 2007; 18(2): 3-8

Using problem-based learning in public health service based training. $2007 ; 18(2): 8-13$

Q

Q fever

A review of the efficacy of human $Q$ fever vaccine registered in Australia. 2007; 18(8): 133-6

Bug Breakfast in the Bulletin: Q fever. 2007; 18(8): 137-8

R

refugees

Bug Breakfast in the Bulletin: refugee health. 2007; 18(2): 26-7

RESIDential Environment Project

Can the impact on health of a government policy designed to create more liveable neighbourhoods be evaluated? An overview of the RESIDential Environment Project. 2007; 18(12): 238-42

Richardson, Benjamin Ward

Will considerations of environmental sustainability revitalise the policy links between the urban environment and health?. 2007; 18(4): 41-5

\section{Ross River virus}

Bug Breakfast in the Bulletin: Ross River virus. 2007; 18(4): $63-4$

\section{$S$}

salmonella

Outbreak of Salmonella Montevideo infections. 2007; 18(2): 28-35

Salmonellosis outbreak. 2007; 18(6): 100-3

schools

Recent substance use and high levels of psychological distress among secondary school students in New South Wales. 2007; 18(8): 125-9

screening

The NSW Health routine screening for domestic violence program. 2007; 18(6): 86-9

sexually transmitted diseases

Bug Breakfast in the Bulletin: Human Papilloma Virus. 2007; 18(6): 97-8

smoking

Recent substance use and high levels of psychological distress among secondary school students in New South Wales. 2007; 18(8): 125-9 


\section{socioeconomic factors}

Crowded suburbs and killer cities: a brief review of the relationship between urban environments and mental health. 2007; 18(12): 222-7

Public health and the potential benefits of Crime Prevention Through Environmental Design. 2007;

standards 18(12): 232-7

Influencing population health performance: introduction of standards for area health services in New South Wales. 2007; 18(2): 17-21

stress

Crowded suburbs and killer cities: a brief review of the relationship between urban environments and mental health. 2007; 18(12): 222-7

Too busy: why time is a health and environmental problem. 2007; 18(12): 219-21

surveillance systems

Bug Breakfast in the Bulletin: refugee health. 2007; 18(2): 26-7

sustainable development

Creating healthy, just and eco-sensitive cities. 2007; 18(4): 37-40

Will considerations of environmental sustainability revitalise the policy links between the urban environment and health?. 2007; 18(4): 41-5

Developing a national approach to building healthy and sustainable cities. 2007 ; 18(4): 45-7

A social-ecological perspective on health in urban environments. 2007; 18(4): 48-50

Checklist for healthy and sustainable communities. 2007; 18(4): 51-4

Healthy, just and eco-sensitive cities: moving forward. 2007; 18(12): 209-12

Can the impact on health of a government policy designed to create more liveable neighbourhoods be evaluated? An overview of the RESIDential Environment Project. 2007; 18(12): 238-42

David Mason's blog. 2007; 18(12): 213

see also environmental impact statements; health impact assessment (HIA)

\section{Sydney Metropolitan Strategy}

Report on the health impact assessment of the Sydney Metropolitan Strategy in greater western Sydney. 2007; 18(4): 40

syphilis

Syphilis. 2007; 18(10): 203-7

\section{$\mathrm{T}$}

\section{teleconferencing}

Use of communication technology among public health professionals in New South Wales, Australia. 2007; 18(2): $13-16$

\section{tuberculosis}

Prevalence of Mantoux positivity and annual risk of infection for tuberculosis in New South Wales prisoners, 1996 and 2001. 2007; 18(8): 119-24

U

\section{United Kingdom}

Health impact assessments in London: assessing the Lord Mayoral strategies. 2007; 18(10): 185-7 urban design see urban health

urban health

Creating healthy, just and eco-sensitive cities. 2007; 18(4): $37-40$

Report on the health impact assessment of the Sydney Metropolitan Strategy in greater western Sydney. 2007; 18(4): 40

Will considerations of environmental sustainability revitalise the policy links between the urban environment and health?. 2007; 18(4): 41-5

Developing a national approach to building healthy and sustainable cities. 2007 ; 18(4): 45-7

A social-ecological perspective on health in urban environments. 2007; 18(4): 48-50

Checklist for healthy and sustainable communities. 2007; 18(4): 51-4

Health impact assessment in urban settings. 2007; 18(10): 149-50

Influencing urban environments for health: NSW Health's response. 2007 ; 18(10): 150-1

International perspective on health impact assessment in urban settings. 2007; 18(10): 152-4

Health impacts of urban development: key considerations. 2007; 18(10): 155-6

A planner's perspective on the health impacts of urban settings. 2007; 18(10): 157-60

Bungendore health impact assessment: urban development in a rural setting. 2007 ; 18(10): 164-5

Greater Granville Regeneration Strategy. 2007; 18(10): 169-71

A health impact assessment of the Liverpool Hospital redevelopment. 2007; 18(10): 172-3

Rapid versus intermediate health impact assessment of foreshore development plans. 2007; 18(10): 174-6

Health and social impact assessment of the South East Queensland Regional Plan (2005-2026). 2007; 18(10): 177-9

Lessons in applying health impact assessment to regeneration schemes: the Victorian experience. 2007; 18(10): 180-1

Greater Christchurch Draft Urban Development Strategy 2005. 2007; 18(10): 182-4

Health impact assessments in London: assessing the Lord Mayoral strategies. 2007; 18(10): 185-7

An overview of the regulatory planning system in New South Wales: identifying points of intervention for health impact assessment and consideration of health impacts. 2007; 18(10): 188-91

Building health impact assessment capacity as a lever for healthy public policy in urban planning. 2007; 18(10): 192-4

Channelling Edwin Chadwick: beyond utopian thinking in urban planning policy and health. 2007; 18(10): 195-7

Health impact assessment and urbanisation. Lessons from the NSW HIA Project. 2007; 18(10): 198-201

Crowded suburbs and killer cities: a brief review of the relationship between urban environments and mental health. 2007; 18(12): 222-7

Public health and the potential benefits of Crime Prevention Through Environmental Design. 2007; 18(12): 232-7

Healthy, just and eco-sensitive cities: moving forward. 2007; 18(12): 209-12 
Can the impact on health of a government policy designed to create more liveable neighbourhoods be evaluated? An overview of the RESIDential Environment Project. 2007; 18(12): 238-42

Seeing obesity as a systems problem. 2007; 18(12): 214-18

Too busy: why time is a health and environmental problem. 2007; 18(12): 219-21

Healthy by Design: an innovative planning tool for the development of safe, accessible and attractive environments. 2007; 18(12): 228-31

The Slow Cities movement. 2007; 18(12): 213

US Centers for Disease Control and Prevention's Healthy Places initiative. 2007; 18(12): 213

World Health Organization Centre for Health Development, Kobe Japan. 2007; 18(12): 213

World Health Organization's Healthy Cities program. 2007; 18(12): 213

V

vaccination see immunisation

videoconferencing

Use of communication technology among public health professionals in New South Wales, Australia. 2007;

violence 18(2): $13-16$

How can the health sector respond to violence? 2007; 18(6): 73-4
Preventing violence in New South Wales: data sources and their adequacy. 2007; 18(6): 75-82

Reducing alcohol-related violence and improving community safety: the Alcohol Linking Program. 2007; 18(6): 83-5

Strengthening the effectiveness of 'whole of government' interventions to break the cycle of violence in disadvantaged communities. 2007 ; 18(6): 94-6 see also domestic violence

W

workforce development

Strengthening learning opportunities to promote the capacity of the public health workforce. 2007; 18(2): 2-3

Problem-based learning in public health workforce training: a discussion of educational principles and evidence. 2007 ; 18(2): 3-8

Using problem-based learning in public health service based training. 2007; 18(2): 8-13

\section{World Health Organization}

Centre for Health Development, Kobe Japan. 2007; 18(12): 213

Healthy Cities program. 2007; 18(12): 213

Y

yellow fever

Factsheet: Yellow fever. 2007; 18(12): 245 